\title{
Distance learning and patient safety: Report and evaluation of an online patient safety course
}

\author{
Johis Ortega, ${ }^{1}$ Maria Cristina Cometto, ${ }^{2}$ Rosa A. Zárate Grajales, ${ }^{3}$ Silvina Malvárez, ${ }^{4}$ Silvia Cassiani, ${ }^{5}$ \\ Carmen Falconi, ${ }^{6}$ Daniel Friedeberg, ${ }^{1}$ and Nilda Peragallo-Montano ${ }^{7}$
}

Suggested citation Ortega J, Cometto MC, Zárate Grajales RA, Malvárez S, Cassiani S, Falconi C, et al. Distance learning and patient safety: report and evaluation of an online patient safety course. Rev Panam Salud Publica. 2020;44:e33. https://doi.org/10.26633/ RPSP.2020.33

ABSTRACT Patient safety is a critical topic in health care globally, with implications for nurses, physicians, administrators,
and most importantly, patients and their well-being. Online distance learning (ODL) is widely accepted among
most disciplines in higher education and has been used to promote patient safety knowledge among health
care students and professionals in diverse contexts. This article reports on an online Nursing and Patient
Safety course developed in 2012 by the University of Miami School of Nursing and Health Studies in conjunc-
tion with the Pan American Health Organization and the International Network for Nursing and Patient Safety.
The study's objectives are to describe the implementation of an international ODL program to enhance patient
safety knowledge in nurses and nursing students, and to examine the participants' assessments of this online
approach as an effective learning tool. Most participants who completed the Nursing and Patient Safety ODL
course reported being satisfied with the course content and experience, and demonstrated increased knowl-
edge on patient safety, as measured by post-module quizzes and self-report. Limitations of the study include
the lack of a comparison group, disparity in the number of participants across the course's language formats
(English, Portuguese, Spanish), and the large number of participants who registered for but did not complete
the course. Future research should identify obstacles to course completion, explore participants' awareness of
patient safety issues and perceived need for more instruction, and look at ways to disseminate the course to
the broadest international population of nurses and nursing students.

Keywords Patient safety; education, nursing; education, distance.

Patient safety is a critical topic in health care with implications for nurses, physicians, administrators, and most importantly, patients and their well-being. It refers to the reduction and mitigation of unsafe actions within the health care system and the use of best practices that lead to optimal outcomes for patients (1). According to the World Health Organization (WHO), "[t]he most important challenge in the field of patient safety must be how to prevent harm" during the health care process, or how to reduce the risk of "unnecessary"

\footnotetext{
1 University of Miami School of Nursing and Health Studies, Miami, FL, United States of America. $\bowtie$ Johis Ortega, j.ortega ${ }^{10} @$ miami.edu

2 Escuela de Enfermería, Universidad Nacional de Córdoba, Córdoba, Argentina

3 Escuela Nacional de Enfermería y Obstetricia, Universidad Nacional Autónoma de México, Mexico City, Mexico

4 Escuela de Enfermería, Universidad Nacional de Rosario, Rosario, Argentina
}

harm to an acceptable minimum (2). An acceptable minimum refers to "the collective notions of given current knowledge, resources available and the context in which care was delivered weighed against the risk of non-treatment or other treatment" (3). Effective strategies, strategic management, trained health care professionals, and active patient engagement are evidence-based and data-driven interventions that can help ensure consistent and significant improvements in patient safety.

\footnotetext{
Health Systems and Services, Pan American Health Organization/World Health Organization, Washington, DC, United States of America

6 Facultad de Enfermería, Pontificia Universidad Católica del Ecuador, Quito, Ecuador

7 School of Nursing, University of North Carolina at Chapel Hill, Chapel Hill, NC, United States of America
} 
There are significant consequences for patients and health care personnel when patient safety is compromised. According to the landmark report, To Err Is Human: Building a Safer Health System, between 44000 and 98000 deaths in the United States resulted from preventable medical errors in hospitals in 1997 - a number that exceeded deaths from motor vehicle accidents, breast cancer, or AIDS (4). Indeed, the biggest challenge in the field of patient safety is how to prevent harm, particularly "avoidable harm" (2). According to the WHO, one in ten hospitalized patients experience harm, and half of these incidents can be categorized as preventable (2). Preventable medication errors alone result in a loss of $\$ 42$ billion globally every year (2), and this cost escalates each year errors go unaddressed. Along with this heavy financial burden, there is a diminution in public trust, as well as a loss of morale among health care personnel when a patient develops a complication or dies from a preventable medical error. The WHO has found that most errors are caused by faulty systems, processes, and conditions that increase the incidence of errors, as well as from human factors; thus, mistakes can be avoided by designing health information systems at all levels to help practitioners and patients make safe health care decisions (2).

The WHO's IBEAS pioneer study of patient safety errors in five Latin American countries found that $10 \%$ of hospitalized patients had experienced a current or recent adverse event and $20 \%$ experienced harm during their hospitalization, including pneumonia, infection, and sepsis. Concluding that almost $60 \%$ of these incidents were preventable, they recommend developing locally-based solutions to increase awareness on patient safety, tailoring interventions to populations at greatest risk, and promoting a culture of patient safety among health care providers (5). The WHO has developed a number of initiatives (2) to promote expertise, innovation, and involvement in patient safety globally, focusing on collaboration and capacity-building among stakeholders including patients, providers, organizational leaders, researchers, policymakers, and industry. These initiatives include "global patient safety challenges" focusing on medications (6), clean care and safe surgical practices; strengthening knowledge transfer and technical capacity; empowering patients and families to serve as safety advocates; a health care professions curriculum guide; developing organizational leadership capacity; technical training for primary care settings; measuring, collecting, and analyzing data on patient safety incidents; and monitoring the efficacy of health care system improvements (2). In the context of challenges faced by developing countries, Johnston et al. report on a fellowship to prepare physicians to lead interdisciplinary patient safety initiatives in resource-limited health care environments (7), while Elmonstri et al. propose a holistic, integrated, patient-centered approach to improving patient safety that engages political leaders and stakeholders, empowers regulatory bodies, promotes a culture of safety, supports research and technology infrastructures, and prioritizes patient safety in health care education (8).

Online distance learning (ODL) is widely accepted among most disciplines in higher education, including nursing, and leads to many positive performance results; indeed, it has become the "new normal" study method (9), offering students a high degree of flexibility and convenience (10), and thus eliciting active involvement in the online learning environment. Research on training using mobile devices, or
mLearning, has demonstrated students' widespread use of these devices to achieve their training goals using digital technologies (11).

ODL has been used to promote patient safety knowledge among health care students and professionals in diverse contexts, including improving systems-level thinking as well as attitudes toward and knowledge about patient safety in medical students (12), and internationally, preparing graduate-level health professionals to rebuild health systems in fragile and conflict-affected areas (13). In a review of 22 eLearning studies focusing on continuing education for registered nurses in a broad range of countries, Rouleau et al. found that most of the studies reported favorable outcomes for nurses' satisfaction, learning, and skills; however, the authors identified a need for research to understand how and whether nurses are applying their new knowledge to their work, and how factors such as patient outcomes and cost containment may be impacted (14).

Given these overall positive results, it seems clear that there are many reasons why nursing students may choose ODL for postgraduate education. Ballman et al. suggest it allows registered nurses to pursue higher degrees without having to leave their clinical positions (15), and report that students demonstrate digital literacy and are comfortable with the online learning environment. Merrill describes today's nursing students as the NET Generation, a group that came of age in a "media-rich" world and expects to use online technologies in education; thus, faculty and nursing school curriculums must adapt to new learning preferences that may challenge traditional teaching methods (16). At the same time, according to Neville et al. (17), even tech-savvy health professional educators (HPEs) may encounter challenges when integrating online technology into their didactic work. After taking a postgraduate ODL course on using information and communication technology (ICT) in health care education, HPEs reported greater confidence in using ICT but felt less in control of the technologies; the authors attribute this outcome to an experience of increased cognitive load, and propose that future research investigate the role of metacognition and cognitive load in the development of HPEs' perception of ICT control within the context of health professional education (17).

Despite the massive development and benefits of ODL in education, its successful implementation and the full realization of its potential depend on whether students as well as faculty are willing to accept and adopt the technology (18-20). Consequently, it is crucial for education professionals and policy makers to consider the factors that affect the user's acceptance of Internet-based learning platforms, as well as educators' ability and inclination to design and implement ODL courses. As suggested by recent studies, implementation of eLearning is not merely a technological solution, but also a process involving sociocultural and individual behavioral factors $(16,21,22)$ as well considerations of confidence, locus of control, cognitive load, and metacognition (17).

This report describes a free, online patient safety course developed in 2012 by the University of Miami School of Nursing and Health Studies (SONHS) in conjunction with the Pan American Health Organization (PAHO) and the International Network for Nursing and Patient Safety (INNAPS). The course targets nurses and nursing students and discusses topics such as proper hygiene, fall prevention, medication errors, and 
patient rights; it is offered in English, Portuguese, and Spanish. We discuss the course's purpose, design, components, and implementation; report on user demographics and how they evaluated the course; and suggest improvements for future iterations of this course. The report's objectives are to describe the implementation of an international ODL program to increase knowledge about patient safety in nurses and nursing students, and to examine participants' assessments of this online approach as an effective learning tool to enhance patient safety.

\section{Course description and development}

The Nursing and Patient Safety course is an open-ended distance-learning course designed to help practicing nurses and nursing students learn and maintain skills related to the provision of safe patient care. It is an interactive compilation of up-to-date, authoritative nursing guidelines as they apply to the most urgent safety concerns of patients today. Its content draws from multiple sources, including the WHO and the Joint Commission's Patient Safety Solutions. The program discusses important patient safety risks with specific recommendations for patient damage avoidance and risk minimization.

The course is hosted on Moodle, a free and open-source learning management system, and is accessed at patientsafetycourse.org. An introduction is followed by 11 modules; 9 patient care approaches are divided into 7 of the modules, and issues central to the nurse's role in supporting patient safety are covered in the 4 remaining modules (Table 1). A glossary of key terms and a list of additional resources can be consulted at any point during the course.

Before beginning the first module, students must complete a 17-item registration which includes questions about their demographics, educational background, and roles in the nursing profession. To receive a certificate of completion, students must complete all 11 modules and pass each module's quiz with a score of $100 \%$. Each quiz is comprised of 10 multiple-choice questions; students are able to retake them as many times as needed until they obtain $100 \%$ correct answers. Students are also required to complete a course evaluation consisting of 12 items rated on a 5-point scale ("strongly agree" to "strongly disagree"); an opportunity to provide open-ended comments is also offered.

As a WHO Collaborating Centre for Nursing Workforce Development and Patient Safety, the University of Miami School of Nursing and Health Studies has a mandate from the $\mathrm{WHO}$ and PAHO to promote patient safety in nursing through programs such as the online Nursing and Patient Safety course. This mandate is further strengthened by SONHS's membership in INNAPS. SONHS developed the course in collaboration with PAHO and INNAPS. In a workshop setting, INNAPS members and PAHO representatives reviewed the content developed by the SONHS team to ensure it was relevant, comprehensive, concise, and culturally appropriate for nurses in the Americas and throughout the world; changes were made through a consensus-building process. Course dissemination was achieved through SONHS, PAHO, WHO, and INNAPS. The members of this network are mainly from Latin America and the Caribbean, and through their contacts in the education and health sectors, the course has been disseminated throughout educational institutions and hospitals in the hemisphere.

TABLE 1. Nursing and Patient Safety course: content and objectives

\section{Module Name \\ 1. Improved Hand Hygiene to Prevent Health Care-Associated Infections}

2. Patient Identification

\section{Communication During Patient Handovers}

4. Medication Safety Basics

\section{Additional Topics in Medication Safety}

\section{Assuring} Medication Accuracy at Transitions in Care

7. Fall Prevention

\section{Pressure Ulcer Prevention}

\section{Psychologica Wellbeing}

10. Safe Procedures

11. Patient Rights
- Describe the five moments of hand hygiene

- Match the correct hand hygiene method to the clinical situation

- Apply correct hand hygiene techniques to your nursing practice

- Describe the appropriate steps to be used in patient identification

- Describe the appropriate steps for labeling lab specimens

- Identify interventions to help prevent patient identification errors

- Define the SBAR communication technique

- Describe each element of the SBAR communication technique

- Evaluate the use of the SBAR technique in different situations

- Describe the "five rights" of medication administration

- Describe the additional proposed "rights" of medication administration

- Identify situations in which medication errors could occur

- Describe the proper use of injection device

- Identify high-alert medications

- Identify safe nursing interventions during the administration of high-alert medications

- Identify safe nursing interventions to prevent catheter and tubing misconnections

- Describe the steps of a proper medication reconciliation process

- Identify situations in which medication reconciliation is necessary

- Describe the potential consequences of an inadequate medication reconciliation process

- Identify safe nursing interventions to prevent errors during the medication reconciliation process

- Describe the elements of the Morse Fall Scale

- Apply Morse scale to identify patients at risk for falls

- Identify nursing interventions to prevent falls

- Describe risk factors that contribute to the development of pressure ulcers

- Identify the elements of the Norton Scale

- Apply the Norton Scale to identify patients at high risk of developing pressure ulcers

- Identify nursing interventions to prevent pressure ulcers

- Analyze the concept of psychological wellbeing and its dimensions

- Understand that psychological wellbeing is an integral part of quality nursing care

- Identify the care strategies that ensure psychological wellbeing

- Describe the elements of pre-procedure verification

- Identify the correct steps of "time out"

- Identify situations in which "time out" must be done

- Recognize that respect for patients' rights is an integral part of the concept of patient safety

- Identify actions that promote patients' rights

- Give examples of how legislation has provided mechanisms by which patients' rights are protected

SBAR: Situation, Background, Assessment, Recommendation Source: prepared by authors from the study results. 


\section{RESULTS}

\section{Participant characteristics}

The sample data were compiled from responses submitted to the course registration page through January 2019. A total of 16412 nurses and nursing students completed the registration (Table 2) and opted to take the course in one of three languages $($ Spanish $=13166$ [80.2\%]; English = 1992 [12.1\%]; Portuguese = $1254[7.6 \%])$. Across all three language formats, the majority of those registering were female (Spanish $=10968$ female $[66.8 \%$ of all registrants]; English = 1522 [9.3\%]; Portuguese = 1060 $[6.6 \%])$. At least three-quarters of registrants within each language format were female $(84.5 \%$ of Portuguese speakers were female, $83.3 \%$ of Spanish speakers, and $76.4 \%$ of English speakers). On average, registrants were in their early thirties (Spanish $=30.1$ years; English = 31.4; Portuguese $=33.2$ ).

Of all of the registrants, 7999 (48.7\%) were practicing nurses (Spanish $=6191$ nurses [37.7\% of all registrants]; English $=1107$ [6.7\%]; Portuguese $=701[4.3 \%])$ and $8413(51.3 \%)$ were nursing students (Spanish $=6975$ students [42.5\% of all registrants]; English $=885[5.4 \%]$; Portuguese $=553[3.4 \%])$. A greater percentage of nursing students (53\%) than nurses (47\%) registered for the course in Spanish, while for the English and Portuguese courses a greater percentage of nurses $(55.6 \%$ and $55.9 \%$ respectively) registered than nursing students (44.4\% and $44.1 \%$ ).

Registrants came from 107 countries and six continents (Table 3). The Spanish-speaking countries with the highest number of participants were Colombia (5 089; 31\% of all registrants), Ecuador (2 939; 18\%), and Argentina (2 144; 13\%). Of the Portuguese-speaking countries, Brazil (2 010; 12\% of all registrants) had the highest number of participants. The English-language format was accessed predominantly by students from the United States (500; 3\% of all registrants) and Saudi Arabia (258; $1.6 \%)$.

\section{Course completion and evaluation}

Participants who completed all 11 of the quizzes following each module were counted as having completed the course. Of the 16412 participants who registered for the course, 11525 (70.2\%) attempted the first quiz and went on to complete the course. Students were required to complete a course evaluation before accessing the certificate of completion. Evaluations were

TABLE 2. Demographics of participants registered for the Nursing and Patient Safety course $(\mathrm{N}=16412)$

\begin{tabular}{lcccccccc} 
& \multicolumn{2}{c}{ Spanish } & \multicolumn{2}{c}{ English } & \multicolumn{2}{c}{ Portuguese } & \multicolumn{2}{c}{ Totals } \\
\cline { 2 - 8 } & $n$ & $\%$ & $n$ & $\%$ & $n$ & $\%$ & $n$ & $\%$ \\
Male & 2198 & $(16.7)$ & 470 & $(23.6)$ & 194 & $(15.5)$ & 2862 & $(17.4)$ \\
Female & 10968 & $(83.3)$ & 1522 & $(76.4)$ & 1060 & $(84.5)$ & 13550 & $(82.6)$ \\
Students & 6975 & $(53)$ & 885 & $(44.4)$ & 553 & $(44.1)$ & 8413 & $(51.3)$ \\
Nurses & 6191 & $(47)$ & 1107 & $(55.6)$ & 701 & $(55.9)$ & 7999 & $(48.7)$ \\
Total registration & 13166 & $(80.2)$ & 1992 & $(12.1)$ & 1254 & $(7.6)$ & 16412 & $(100)$
\end{tabular}

Source: prepared by authors from the study results.
TABLE 3. Participants registered for the Nursing and Patient Safety course, by country and language $(\mathrm{N}=16412)$

\begin{tabular}{|c|c|c|c|c|}
\hline \multirow[t]{2}{*}{ Country } & \multicolumn{4}{|c|}{ Number of Participants } \\
\hline & English & Spanish & Portuguese & Total \\
\hline Argentina & 42 & 2083 & 19 & 2144 \\
\hline Belize & 93 & 10 & 0 & 103 \\
\hline Bolivia & 2 & 108 & 3 & 113 \\
\hline Brazil & 60 & 27 & 1123 & 1210 \\
\hline Chile & 0 & 54 & 0 & 54 \\
\hline Colombia & 174 & 4862 & 53 & 5089 \\
\hline $\begin{array}{l}\text { Dominican } \\
\text { Republic }\end{array}$ & 5 & 119 & 0 & 124 \\
\hline Ecuador & 139 & 2776 & 24 & 2939 \\
\hline Egypt & 75 & 2 & 0 & 77 \\
\hline EI Salvador & 12 & 152 & 3 & 167 \\
\hline Honduras & 50 & 955 & 10 & 1015 \\
\hline India & 104 & 0 & 0 & 104 \\
\hline Jordan & 69 & 0 & 0 & 69 \\
\hline Mexico & 44 & 1041 & 3 & 1088 \\
\hline Nicaragua & 0 & 76 & 0 & 76 \\
\hline Nigeria & 25 & 0 & 0 & 25 \\
\hline Peru & 23 & 286 & 7 & 316 \\
\hline Philippines & 39 & 0 & 0 & 39 \\
\hline Puerto Rico & 0 & 28 & 0 & 28 \\
\hline Qatar & 37 & 1 & 0 & 38 \\
\hline $\begin{array}{l}\text { Saudi } \\
\text { Arabia }\end{array}$ & 258 & 0 & 0 & 258 \\
\hline Spain & 29 & 426 & 0 & 455 \\
\hline $\begin{array}{l}\text { United Arab } \\
\text { Emirates }\end{array}$ & 35 & 1 & 0 & 36 \\
\hline $\begin{array}{l}\text { United } \\
\text { States }\end{array}$ & 467 & 29 & 4 & 500 \\
\hline Uruguay & 1 & 30 & 0 & 31 \\
\hline Other $^{1}$ & 209 & 100 & 5 & 314 \\
\hline Total & 1992 & 13166 & 1254 & 16412 \\
\hline
\end{tabular}

${ }^{1}$ Countries with fewer than 25 participants: Andorra (1); Angola (1); Antigua and Barbuda (2); Australia (11); Austria (1); Bahamas (4); Bahrain (2); Bangladesh (6); Barbados (1); Belgium (2); Botswana (1); Cambodia (2); Canada (15); China (6); Comoros (5); Congo (2); Costa Rica (18); Cuba (5); Cyprus (1); Dominica (3); Ethiopia (2); Fiji (1); Georgia (2); Germany (2); Ghana (7); Greece (2); Guatemala (23); Guyana (14); Haiti (1); Holland (1); Hong Kong (1); Iceland (1); Indonesia (2); Iran (4); Iraq (1); Ireland (4); Israel (1); Italy (9); Jamaica (6); Kenya (4); Kuwait (3); Lebanon (3); Lesotho (1); Libya (3); Malaysia (5); Maldives (3); Mali (1); Malta (1); Mauritius (1); Monaco (1); Mozambique (2) Netherlands (5); New Zealand (4); Norway (1); Oman (6); Pakistan (9); Panama
(4): Paraguay (9); Poland (1): Portugal (2); Russian Federation (1): Saint Lucia (1): Serbia (1); Sierra Leone (1); (4); Paraguay (9); Poland (1); Portugal (2); Russian Federation (1); Saint Lucia (1); Serbia (1); Sierra Leone (1);

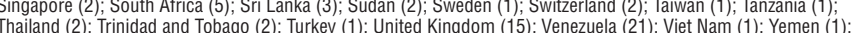
Thailand (2); Trinidad and Toba

Note: language refers to the language in which the course was taken

Source: prepared by authors from the study results.

overwhelmingly positive across all language formats (Table 4), with $98.9 \%$ of respondents agreeing or strongly agreeing that they felt positively about the course. Similarly, almost all students $(97 \%)$ agreed or strongly agreed that the course was relevant to their nursing practice; that it was culturally appropriate for them $(97.7 \%)$; that they learned something new $(98.4 \%)$; that they could apply their new knowledge toward their nursing practice $(98.6 \%)$; and that they would recommend the course to a colleague $(98.8 \%)$.

\section{DISCUSSION}

ODL depends on technology and its continued advances to support students through essential components such as online discussion, instructor feedback, and evaluation (23). Many 
TABLE 4. Course evaluation ( $\mathrm{N}=11525)$

\begin{tabular}{|c|c|c|c|c|c|c|c|c|c|c|c|c|}
\hline \multirow[t]{2}{*}{ Evaluation Items } & \multicolumn{2}{|c|}{$\begin{array}{l}\text { Strongly } \\
\text { Agree } 5 \\
\end{array}$} & \multicolumn{2}{|c|}{ Agree 4} & \multicolumn{2}{|c|}{ Neutral 3} & \multicolumn{2}{|c|}{ Disagree 2} & \multicolumn{2}{|c|}{$\begin{array}{c}\text { Strongly } \\
\text { Disagree } 1 \\
\end{array}$} & \multicolumn{2}{|c|}{$\begin{array}{l}\text { No Answer } \\
\text { N/A }\end{array}$} \\
\hline & $n$ & $\%$ & $n$ & $\%$ & $n$ & $\%$ & $n$ & $\%$ & $n$ & $\%$ & $n$ & $\%$ \\
\hline My overall evaluation of the course is positive & 9158 & $(79.5)$ & 2239 & $(19.4)$ & 89 & $(0.8)$ & 5 & $(0.04)$ & 26 & $(0.2)$ & 8 & $(0.06)$ \\
\hline I would recommend this course to a colleague & 9279 & $(80.5)$ & 2117 & $(18.3)$ & 90 & $(0.8)$ & 10 & $(0.1)$ & 18 & $(0.2)$ & 11 & $(0.1)$ \\
\hline The course material is presented effectively & 7894 & $(68.5)$ & 3199 & $(27.8)$ & 358 & $(3.1)$ & 28 & $(0.2)$ & 35 & $(0.3)$ & 11 & $(0.1)$ \\
\hline The material in the modules reflects the learning objectives of the course & 7996 & $(69.4)$ & 3291 & $(28.6)$ & 204 & $(1.8)$ & 17 & $(0.14)$ & 9 & $(0.1)$ & 8 & $(0.06)$ \\
\hline This course has challenged me to think & 7802 & $(67.7)$ & 3266 & $(28.3)$ & 373 & $(3.2)$ & 46 & $(0.4)$ & 15 & $(0.1)$ & 23 & $(0.2)$ \\
\hline The quizzes accurately assessed what I have learned in this course & 7836 & (68) & 3389 & $(29.4)$ & 245 & $(2.2)$ & 24 & $(0.2)$ & 13 & $(0.1)$ & 10 & $(0.1)$ \\
\hline The material was culturally appropriate to me & 8246 & $(71.5)$ & 3015 & $(26.2)$ & 225 & $(1.9)$ & 18 & $(0.2)$ & 12 & $(0.1)$ & 9 & $(0.1)$ \\
\hline I learned something new & 9039 & $(78.4)$ & 2310 & (20) & 149 & $(1.3)$ & 8 & $(0.06)$ & 11 & $(0.1)$ & 8 & $(0.06)$ \\
\hline I am confident that I can apply what I have learned to my nursing practice & 9233 & $(80.1)$ & 2132 & (18.5) & 120 & (1.1) & 11 & $(0.1)$ & 9 & $(0.1)$ & 7 & $(0.1)$ \\
\hline
\end{tabular}

researchers propose that ODL's mixed-media courseware, in combination with traditional learning formats, can contribute to new learning opportunities, improved learning performance, and improved self-direction in professional education $(9,10$, 23). These technologies, flexible formats and supports ensure that ODL learners can remain in their jobs and home countries; thus, the convenience offered by ODL is central to meeting the needs of adult learners, allowing them to work at any time, from any location, and at their own pace (24). One of the most encouraging results from the Nursing and Patient Safety course was the highly positive evaluations submitted by the participants. These results suggest that the Nursing and Patient Safety course's ODL format was an effective vehicle for imparting new knowledge, and that this knowledge was deemed by participants to be relevant, culturally-competent, and applicable to real-world professional health care environments in both developed and developing countries globally.

While all countries must address factors that contribute to poor health care systems, the major contributors to unsafe patient care in low-to-middle-income countries are understaffing, inadequate facilities, overcrowding, insufficient health care supplies, shortage of basic equipment, and poor hygiene and sanitation. According to the WHO, a study of adverse events and deaths in 26 low- and middle-income countries found that "the rate of adverse events was around $8 \%$, of which $83 \%$ could have been prevented and 30\% led to death" (2). Nurses are ideally placed to drive the safety and quality agenda of health care, particularly in low- and middle-income countries. However, studies have shown that nursing education programs inadequately equip students with the skills to mitigate patient safety issues; for example, according to Ball and Douglas (25), the most common factor associated with errors and patient safety is the lack of appropriate education. Thus, there is a growing consensus within the health care community about the need to explicitly encourage patient safety instruction (26). The Nursing and Patient Safety course provides easily accessible, comprehensive, standardized instruction in the most important aspects of patient safety free of charge to any nurse or nursing student worldwide. Moreover, hospitals and nursing schools can integrate the course into their professional continuing education efforts or their school curriculums to address gaps in their own training or education platforms while broadening the reach and potential impact of the course.

Although little comprehensive research has been done comparing the benefits and pitfalls of institutional versus distance learning, there is universal agreement that access to learning, course flexibility, and student satisfaction are enhanced through distance learning processes and, in most cases, are cost-effective for the institution and economically beneficial for the student. Studies have shown that online education has benefitted an increasing number of students and increasingly diverse populations (27), and that ODL is as effective as the conventional in-house model (28). In a literature review of the effectiveness of online learning, Nguyen observes that 92\% of ODL studies demonstrate similar or greater effectiveness than classic education models, with improved learning outcomes as documented by "test scores, student engagement with the class material, improved perception of learning and of the online format, stronger sense of community among students, and reduction in withdrawal or failure" (23). The standardization of study topics made possible by online instruction also benefits diverse student bodies. Because courses are designed and disseminated with standard templates, students at different learning levels and from different backgrounds and cultures are provided the same information. There is no variation in delivery, testing, or evaluation (28). 
The Nursing and Patient Safety course builds on the welldocumented effectiveness of ODL formats to increase patient safety awareness and knowledge in nurses and nursing students. Moreover, it shares the strengths and advantages of other ODL programs, including low cost, availability, accessibility, convenience, and flexibility, thus bringing much-needed instruction to populations and settings that may not have the resources to implement such instruction on their own.

\section{Conclusions}

The Nursing and Patient Safety course has been an overwhelming success since its implementation in 2012. Although we cannot establish a direct link between the course and the number of lives saved or complications mitigated, there is strong reason to believe it has contributed to the overall increase in patient safety awareness internationally, and especially in the developing world. The course's availability in three languages means it can be taken by nurses in diverse countries, and its ease of access and cost-free availability have contributed to its global reach. These encouraging results have led to great enthusiasm for the course; a second online patient safety course is in the initial stages of development, with a new set of modules planned for late 2020 .

\section{Limitations}

This study is limited by its lack of a comparison group of nurses and nursing students exposed to the same patient safety content by a live instructor within a physical classroom setting. Thus, we cannot state whether such a group would have mastered the content more quickly or thoroughly, or whether they would have been more likely to achieve a $100 \%$ score on the module quizzes on their first try, as compared to the participants who completed the online Nursing and Patient Safety course. A future study might randomly assign participants to classroom or ODL versions of the same course to compare their effectiveness. However, we do feel confident in concluding that participants who completed the online course learned the material well enough to pass all of the quizzes at $100 \%$, and that almost all of them rated the course positively. Importantly, in limited-resource environments where instructors and classrooms are not readily available, or in settings such as remote or rural areas where nurses and nursing students may find it difficult to attend classes, this ODL course provides a free, easily accessible opportunity to acquire standardized, comprehensive, culturally-competent knowledge on patient safety procedures and their applications in real-world clinical settings.

The disparity in the number of participants across the different language formats can likely be attributed to the method of course dissemination. As most of the contacts of PAHO,
INNAPS, and SONHS members are in Latin America, a majority of participants elected to take the Spanish version of the course. For future course iterations, efforts will be undertaken to make the course available in more countries.

Future research will focus on how to assess the effectiveness of the course more fully and how to improve our course format. Including a pre-test at the beginning of the entire course or prior to each module will help us to assess the knowledge participants gain as they proceed through the course. We also hope to identify factors that contribute to the success of ODL among nursing students, and well as the challenges they encounter. For example, we know that a sizable number of participants $(4887 ; 29.8 \%$ ) who registered for the course did not complete it. Tudor Car et al. identify important challenges to the successful implementation of eLearning, including expense, limited Internet or technology resources at the organizational or individual levels, limited digital literacy in students, and lack of protected time for health care personnel to take ODL courses (29). It is possible that factors such as these - as well as a self-directed format that does not provide access to tutors, lack of time, or difficulty understanding the course content - presented insurmountable challenges. While we do not have data to help us understand why the participants in the current study did not finish the course, we can contact future participants to identify challenges and obstacles to course completion and how the course might be modified to address these.

Finally, we would like to explore why participants were motivated to take the course. We know that some were required to complete the course by their schools or hospitals, but we do not know the motivation of the others. Exploring participants' awareness of patient safety issues in their countries, as well as their perceived need for more instruction on this topic, can help us tailor our outreach to ensure the course is disseminated to the broadest possible population of nurses and nursing students, and to enhance its potential to improve patient safety throughout our hemisphere as well as globally.

Author contributions. All authors were key contributors to this paper. They conceived the original idea, collected data, analyzed the data, contributed to data analysis and/or wrote the paper. All authors reviewed and approved the final version.

Conflicts of interest. None declared.

\section{Funding. None declared.}

Disclaimer. Authors hold sole responsibility for the views expressed in the manuscript, which may not necessarily reflect the opinion or policy of the RPSP/PAJPH and / or the Pan American Health Organization (PAHO).

\section{REFERENCES}

1. Monrouxe LV, Rees CE. Healthcare professionalism: improving practice through reflections on workplace dilemmas. Chichester, West Sussex: John Wiley \& Sons; 2017. p.110.

2. World Health Organization. Patient safety: making health care safer [Internet]. Geneva: WHO; 2017 [Accessed 2018 Nov 29].
20 p. Available from: http://www.who.int/iris/handle/10665/ 255507

3. World Health Organization. Conceptual framework for the international classification for patient safety: version 1.1 [Final technical report]. Geneva: WHO; 2009 January. [Accessed 2020 February 28]. 
Availablefrom:https://apps.who.int/iris/bitstream/handle/10665 /70882/WHO_IER_PSP_2010.2_eng.pdf

4. Institute of Medicine. To err is human: building a safer health system [Internet]. Washington, DC: The National Academies Press: 1999 Nov [cited 2018 Nov 29]. 312 p. Available from: https:// pubmed.ncbi.nlm.nih.gov / 25077248-to-err-is-human-building-asafer-health-system/ doi: 10.17226/9728

5. World Health Organization. IBEAS: a pioneer study on patient safety in Latin America. Geneva: WHO; 2011. [Accessed 2020 Jan 7]. 16 p. Available from: https://www.who.int/patientsafety/ research/ibeas_report_en.pdf

6. World Health Organization. Medication without harm - Global patient safety challenge on medication safety [Internet]. Geneva: WHO; 2017 [Accessed 2020 Jan 7].16p. Available from: https:/ / www. who.int/patientsafety/medication-safety/medication-withoutharm-brochure/en/

7. Johnston BE, Lou-Meda R, Mendez S, Frush K, Milne J, Fitzgerald T, et al. Teaching patient safety in global health: lessons from the Duke Global Health Patient Safety Fellowship. BMJ Glob Health [Internet]. 2019 Jan [cited 2020 Jan 7]. Available from: https://gh.bmj. com/content/4/1/e001220 doi: 10.1136/ bmjgh-2018-001220

8. Elmontsri M, Banarsee R, Majeed A. Improving patient safety in developing countries - moving towards an integrated approach. J R Soc Med. 2018;9(11):1-5. doi: 10.1177/2054270418786112

9. Alharbi HA, Almutairi AF, Alhelih EM, Alshehry AS. The learning preferences among nursing students in the King Saud University in Saudi Arabia: a cross-sectional survey. Nurs Res Pract. 2017;2017:3090387. doi: 10.1155/2017/3090387

10. Irinoye O, Ayamolowo S, Tijnai OK. Part-time undergraduate nursing students' perception and attitude to ICT supports for distance education in nursing in Nigeria. Malaysian Online Journal of Educational Technology. 2016;4(2):8-21.

11. Colella CM, Rota MJ, Beery T. An interprofessional approach to a distance learning dilemma. Journal of Teaching and Learning with Technology. 2015;4(1):64-8.

12. Gaupp R, Körner M, Fabry G. Effects of a case-based interactive e-learning course on knowledge and attitudes about patient safety: a quasi-experimental study with third-year medical students. BMC Med Educ. 2016;16:172. Available from: https://bmcmededuc.biomedcentral.com/articles/10.1186/s12909-016-0691-4 doi: 10.1186/s12909-016-0691-4

13. KIT Royal Tropical Institute [Internet]. Amsterdam: KIT Royal Tropical Institute; c2019-2020. Rebuilding disrupted health systems developing context-specific strategies for health care policies, implementation and governance (e-learning) (RDHS-E); [cited 2020 Jan 23]. Available from: https://www.kit.nl/study/course/ rebuilding-disrupted-health-systems-developing-context-specificstrategies-health-care-policies-implementation-governance-elearning-rdhs-e/

14. Rouleau G, Gagnon M, Côté J, Payne-Gagnon J, Hudson E, Dubois C, et al. Effects of e-learning in a continuing education context on nursing care: systematic review of systematic qualitative, quantitative, and mixed-studies reviews. J Med Internet Res. 2019;21(10):e15118. Published 2019 Oct 2. doi:10.2196/15118
15. Ballman K, Garritano N, Beery T. Broadening the reach of standardized patients in nurse practitioner education to include the distance learner. Nurse Educ. 2016;41(5):230-3.

16. Merrill EB. Integrating technology into nursing education. ABNF J. 2015;26(4):72-3.

17. Neville V, Lam M, Gordon CJ. The impact of eLearning on health professional educators' attitudes to information and communication technology. J Multidiscip Healthc. 2015(8):75-81. Published 2015 Jan 29. doi:10.2147/JMDH.S74974.

18. Graber J. Comparison of face-to-face and distance learning teaching modalities in delivering therapeutic crisis management skills. Paper presented at: STTI $26^{\text {th }}$ International Nursing Research Congress; 2015 Jul. 23-27; San Juan, PR.

19. Hampton D, Pearce PF. Student engagement in online nursing courses. Nurse Educ. 2016;41(6):294-8.

20. Hampton D, Pearce PF, Moser DK. Preferred methods of learning for nursing students in an on-line degree program. J Prof Nurs. 2017:33(1):27-37.

21. Kurucz S, Rietze L, Lim A, Swamy M. Web-based learning: a bridge to meet the needs of Canadian nurses for doctoral education. Canadian Journal of Higher Education. 2015;45(1):37-47.

22. Lahti M, Hatonen $H$, Valimaki M. Impact of e-learning on nurses and student nurses' knowledge, skills, and satisfaction: a systematic review and meta-analysis. Int J Nurs Stud. 2014;51(1):136-49.

23. Nguyen T. The effectiveness of online learning: beyond no significant difference and future horizons. Merlot Journal of Online Learning and Teaching. 2015;11(2):309-19.

24. Mantas J, Hasman A. IMIA educational recommendations and nursing informatics. In: Murphy J, Goossman W, Weber P, eds. Forecasting Informatics Competencies for Nurses in the Future of Connected Health. Proceedings of the Nursing Informatics Post Conference; 2016 Jun; Geneva, Switzerland. Amsterdam: IOS Press; 2017.

25. Ball MJ, Douglas JV. Redefining and improving patient safety. Methods Inf Med. 2002;41(4):271-6.

26. Davies AE, Amewonye F, Gross J. The role of distance learning in BSc nursing education. West African Journal of Nursing. 2015;26(1):36-51.

27. Skiba DJ. On the horizon: implications for nursing education. Nurs Educ Perspect. 2015;36(4):263-6.

28. Clark M, Julmisse M, Marcelin N, Merry L, Tuck J, Gagnon AJ. Strengthening healthcare delivery in Haiti through nursing continuing education. Int Nurs Rev. 2015;62(1):54-63.

29. Tudor Car L, Kyaw BM, Atun R. The role of eLearning in health management and leadership capacity building in health system: a systematic review. Hum Resour Health. 2018;16(44):1-9. Published 2018 Sep 3. doi:10.1186/s12960-018-0305-9

Manuscript received on 8 September 2019. Revised version accepted for publication on 3 February 2020 


\section{Educación a distancia y seguridad del paciente: informe y evaluación de un curso en línea sobre seguridad del paciente}

RESUMEN La seguridad del paciente es un tema fundamental en la atención de la salud a nivel mundial, con repercusiones para los enfermeros, médicos, administradores y, lo que es más importante, para los pacientes y su bienestar. La educación a distancia en línea está ampliamente aceptada en la mayoría de las disciplinas de enseñanza superior y se ha empleado para difundir los conocimientos en materia de seguridad del paciente a los estudiantes de atención de salud y los profesionales en diversos contextos. En este artículo se informa sobre el curso en línea de enfermería y seguridad del paciente creado en el 2012 por la facultad de enfermería y estudios de salud de la Universidad de Miami, conjuntamente con la Organización Panamericana de la Salud y la Red Internacional de Enfermería y Seguridad del Paciente. Los objetivos del estudio son describir la ejecución de un programa internacional de educación a distancia en línea para mejorar el conocimiento sobre la seguridad del paciente de los enfermeros y los estudiantes de enfermería, y examinar las evaluaciones de los participantes sobre este enfoque en línea como herramienta eficaz de aprendizaje. La mayoría de los participantes en este curso afirmó sentirse satisfecho con su contenido y experiencia, y demostró un mayor conocimiento sobre la seguridad del paciente, de acuerdo con las mediciones de las encuestas posteriores al módulo y la autoevaluación. Entre las limitaciones del estudio se aprecia la falta de un grupo de comparación, una disparidad en el número de participantes entre las diferentes versiones lingüísticas del curso (español, inglés y portugués) y el gran número de participantes que se inscribieron sin llegar a finalizar el curso. Las futuras investigaciones deberán indicar cuáles son los obstáculos para la finalización del curso, explorar la concienciación de los participantes en temas relativos a la seguridad del paciente y las necesidades que perciben de una instrucción más profunda, así como considerar modos de mayor difusión del curso en la comunidad internacional de enfermeros y estudiantes de enfermería.

Palabras clave Seguridad del paciente; educación en enfermería; educación a distancia.

\section{Aprendizagem à distância e segurança do paciente: descrição e avaliação de um curso online sobre segurança do paciente}

RESUMO A segurança do paciente é um tema fundamental para a assistência de saúde em todo o mundo, com implicações para enfermeiros, médicos, administradores e, mais importante ainda, para os pacientes e o seu bem-estar. A educação à distância online (EDO) conta com grande aceitação na maioria das disciplinas do ensino superior e tem sido utilizada para transmitir conhecimentos sobre segurança do paciente a estudantes e profissionais da saúde em diversos contextos. Este artigo descreve um curso online de Enfermagem e Segurança do Paciente desenvolvido em 2012 pela Faculdade de Enfermagem e Estudos da Saúde da Universidade de Miami, em conjunto com a Organização Pan-Americana da Saúde e a Rede Internacional de Enfermagem e Segurança do Paciente. Os objetivos do estudo são descrever a implementação de um programa internacional de EDO para melhorar os conhecimentos de enfermeiros e estudantes de enfermagem sobre segurança do paciente e examinar a forma como os participantes avaliaram a eficácia desta abordagem online como uma ferramenta de aprendizagem. Em sua maioria, os participantes que completaram o curso online de Enfermagem e Segurança do Paciente afirmaram ter tido uma boa experiência com o curso e estar satisfeitos com o seu conteúdo; além disso, demonstraram maiores conhecimentos sobre segurança do paciente, medidos por questionários aplicados após os módulos e pela autoavaliação. As limitações deste estudo incluem a falta de um grupo de comparação, a disparidade no número de participantes nos diferentes formatos do curso (inglês, português, espanhol) e o grande número de participantes que se inscreveram mas não completaram o curso. A pesquisa futura deve identificar os obstáculos à conclusão do curso, explorar a conscientização dos participantes sobre questões de segurança do paciente e a necessidade de mais instrução e procurar formas de divulgar o curso para uma população internacional mais ampla de enfermeiros e estudantes de enfermagem.

Palavras-chave Segurança do paciente; educação em enfermagem; educação a distância. 